Marquette University

e-Publications@Marquette

Psychology Faculty Research and Publications

Psychology, Department of

3-1-2014

\title{
Muscle Tension Induced after Learning Enhances Long-Term Narrative and Visual Memory in Healthy Older Adults
}

Kristy A. Nielson

Marquette University, kristy.nielson@marquette.edu

Laura L. Wulff

Marquette University

Timothy J. Arentsen

Fuller Theological Seminary

NOTICE: this is the author's version of a work that was accepted for publication in Neurobiology of Learning and Memory. Changes resulting from the publishing process, such as peer review, editing, corrections, structural formatting, and other quality control mechanisms may not be reflected in this document. Changes may have been made to this work since it was submitted for publication. A definitive version was subsequently published in Neurobiology of Learning and Memory, Vol. 109 (March 2014): 144-150. DOI. (C) 2014 Elsevier. Used with permission. 
NOT THE PUBLISHED VERSION; this is the author's final, peer-reviewed manuscript. The published version may be accessed by following the link in the citation at the bottom of the page.

\title{
Muscle tension induced after learning enhances long-term narrative and visual memory in healthy older adults
}

\author{
Kristy A. Nielson \\ Department of Psychology, Marquette University \\ Milwaukee, Wisconsin \\ Laura L. Wulff \\ Department of Psychology, Marquette University \\ Milwaukee, Wisconsin \\ Timothy J. Arentsen \\ Department of Psychology, Fuller Theological Seminary \\ Pasadena, California
}

\begin{abstract}
Arousing events are better remembered than mundane events. Indeed, manipulation of arousal, such as by muscle tension, can influence memory even when it occurs shortly after learning. Indeed, our founding study showed this approach can raise delayed memory performance in older adults to a level comparable to that of unaided young adults. Yet, systematic studies, especially those investigating different modalities or types of memory, have not been done. This study investigated the effects of a brief bout of isometric exercise via handgrip on narrative and visuospatial episodic memory in healthy elders. Forty-seven participants completed the Logical Memory subtest of the Wechsler Memory Scales III (LM) and the Benton
\end{abstract}

[Neurobiology of Learning and Memrory, Vol 109, (March 2014): pg. 144-150. DOI. This article is (C) Elsevier and permission has been granted for this version to appear in e-Publications@Marquette. Elsevier does not grant permission for this article to be further copied/distributed or hosted elsewhere without the express permission from [Elsevier].] 
NOT THE PUBLISHED VERSION; this is the author's final, peer-reviewed manuscript. The published version may be accessed by following the link in the citation at the bottom of the page.

Visual Retention Test (BVRT), followed alternately by no treatment and by moderately squeezing a sand-filled latex ball for 1-min (counterbalanced order and test forms). Isometric exercise significantly increased both positive and negative affect ratings. Retention was tested 2 weeks later. Delayed recall and recognition of LM was enhanced by arousal relative to control, as was recognition of the BVRT. The results extend past findings that muscle tension induced after learning modulates memory consolidation, extending findings in elders to suggest that a simple form of isometric exercise can have practical effects, such as aiding memory for stories and images.

Keywords: Handgrip training, Arousal, Memory modulation, Memory consolidation, Aging

\section{Introduction}

Information and events that are physiologically arousing, whether or not they evoke specific emotional reactions, are often better remembered than neutral or mundane information and events (McGaugh, 2000; Nielson \& Jensen, 1994; Nielson \& Meltzer, 2009). Typically, this enhancement of memory is apparent at longer (e.g., hours, days) vs. shorter retrieval delays (e.g., Costa-Miserachs, Portell-Cortés, Aldavert-Vera, Torras-García, \& Morgado-Bernal, 1994; Revelle \& Loftus, 1992; Torras-Garcia, Portell-Cortés, Costa-Miserachs, \& Morgado-Bernal, 1997). Extensive research has associated this phenomenon with several specific biological consequences of arousal, including catecholamine stress hormones released by the adrenal glands that activate secondary signals in the brain (McGaugh, 2000; Nielson \& Jensen, 1994) and with increased glucose release (Parent, Varnhagen, \& Gold, 1999). Importantly, while heightened arousal typically occurs during the experience, and therefore during the encoding of information and events, empirical studies clearly demonstrate that moderate manipulation of arousal can also enhance memory when it occurs shortly after the event (Gold \& van Buskirk, 1975; McGaugh, 1966; Nielson \& Powless, 2007; Nielson, Radtke, \& Jensen, 1996). As such, inherently arousing events are better remembered later, but so too are non-arousing memoranda and events that are followed soon in time by an unrelated but arousing stimulus (Nielson \& Bryant, 2005; Nielson \& Powless, 2007; Nielson, Yee, \& Erickson, 2005; but see also Liu, Graham, \& Zorawski, 2008). Additionally, emotion regulation strategies and a predisposition

[Neurobiology of Learning and Memrory, Vol 109, (March 2014): pg. 144-150. DOI. This article is (C) Elsevier and permission has been granted for this version to appear in e-Publications@Marquette. Elsevier does not grant permission for this article to be further copied/distributed or hosted elsewhere without the express permission from [Elsevier].] 
towards arousal can influence the effect of arousal on memory (Nielson \& Lorber, 2009). Thus, in addition to informing research about the physiological and neural mechanisms underlying memory, this line of work suggests that the manipulation of arousal during or soon after learning might have potential as a tool in cognitive rehabilitation and memory intervention programs.

One particular technique, muscle tension, such as can be induced via handgrip, can induce arousal quickly and without specific affective quality or directionality (i.e., positive/negative). An acute bout of handgrip muscle tension increases breathing and heart rates, blood pressure (Kluess \& Wood, 2005; Stewart, Montgomery, Glover, \& Medow, 2006), and catecholamine levels, especially in older adults (Kremiński, Cybulski, Ziemba, \& Nazar, 2012). "Optimal" handgrip tension (i.e., of moderate pressure) of at least $30 \mathrm{~s}$ has been associated with improved memory and processing speed (Bills, 1927; Courts, 1939; Stauffacher, 1937; Wood \& Hokanson, 1965), and when induced after learning, it enhances memory for word lists (Nielson \& Jensen, 1994; Nielson et al., 1996). Importantly, in the first study to investigate this approach with older adults, the amount of enhancement was enough to bring older adults' memory performance to the level of unmodulated younger adults, except in those who were taking 'beta-blockers' to treat hypertension, which interfere with the normal catecholaminergic response to arousal (Nielson \& Jensen, 1994; Nielson et al., 1996). Despite its apparent utility, the effectiveness of handgrip tension to modulate memory has not been further investigated in recent years, with these or other types of memoranda nor in other memory systems.

Episodic memory is a primary focus of cognitive aging research because it consistently shows deterioration with advancing age (e.g., Haaland, Price, \& Larue, 2003). Episodic memory has often been subdivided into more specific categories by the type of memoranda being learned. For example, visuospatial memory and visual memory are terms often used to describe episodic memory for pictures or graphical representations, while narrative memory is a term often used to describe verbal episodic memory for stories (cf. Rubin, 2006). Memory subsystems are affected differentially by the aging process (e.g., visual memory may deteriorate more rapidly than narrative or other verbal memory; Haaland et al., 2003; Jenkins, Myerson,

[Neurobiology of Learning and Memrory, Vol 109, (March 2014): pg. 144-150. DOI. This article is (C) Elsevier and permission has been granted for this version to appear in e-Publications@Marquette. Elsevier does not grant permission for this article to be further copied/distributed or hosted elsewhere without the express permission from [Elsevier].] 
Joerding, \& Hale, 2000). Indeed, specifically examining different memory domains can clarify and enhance differential diagnoses in neurodegenerative diseases and advanced age (Chapman et al., 2010; Messinis, Lyros, Georgiou, \& Papathanasopoulous, 2012; Zonderman et al., 1995). Specifically, separate cortical regions and pathways become activated when the type of stimuli being memorized varies (Ariza et al., 2006; Rolls, 2000) and age-related differences in memory may arise from a reliance on slightly different cognitive processes or strategies (Sharps, 1998).

Despite the importance of and diversity inherent in human memory, the literature on human post-event memory modulation has focused heavily on list-learning tasks. Indeed, visual and narrative episodic memory have not been examined in this context. Moreover, other types of episodic tasks such as visual and narrative memory may have greater ecological validity with older adults, given that memory for stories and pictures may be more commonly tested and desirable in their everyday lives than memory for word lists. Thus, the current study examined the effect of memory modulation on delayed narrative and visual memory. As arousal induced via moderate handgrip muscle tension has been previously documented to enhance delayed memory in older adults using other episodic memory tasks (Nielson \& Jensen, 1994; Nielson et al., 1996), a similar method, was employed herein. Importantly, we sought to extend the literature while also simplifying the approach to an inexpensive one that could eventually be used outside the laboratory. Such an approach would be needed if this type of modulation could ever be employed as a memory intervention technique. As such, we used a non-mechanical, sand-filled "squeeze ball" (Isoflex@, Gayla Industries) to induce arousal via handgrip muscle tension. We hypothesized that both delayed narrative and visual memory would be enhanced by moderate arousal induced after learning relative to a control condition.

\section{Method}

\subsection{Participants}

A total of 59 healthy, older adults were recruited from existing subject lists. A multi-dimensional definition of healthy aging was employed (see Peel, Bartlett, \& McClure, 2004) in which all

[Neurobiology of Learning and Memrory, Vol 109, (March 2014): pg. 144-150. DOI. This article is (C) Elsevier and permission has been granted for this version to appear in e-Publications@Marquette. Elsevier does not grant permission for this article to be further copied/distributed or hosted elsewhere without the express permission from [Elsevier].] 
participants lived independently, had an estimated IQ that was in the average range or higher, and were at least 60 years of age.

Participants were excluded if they had formal education below grade 7 , a diagnosis of dementia or other cognitive impairment, uncontrolled hypertension, or other unmanaged medical conditions that could affect either cognitive performance or the response to the experimental manipulation (e.g., neurological conditions, psychiatric Axis I conditions, Parkinson's disease, COPD, diabetes, etc.). While 52 of 59 recruits attended and completed the first session and attended the second session, 3 men and 2 women did not have complete or reliable second session data. Thus, 47 subjects are included in the final analyses (see Table 1). For this within-subject design study, participants were quasi-randomly assigned to arousal order groups, i.e., either Group A (arousal then neutral) or Group B (neutral then arousal).

Table 1. Demographic data and affective ratings and memory data (measured prior to manipulation) by order group (mean (SD)).

\begin{tabular}{|c|c|c|c|}
\hline & $\begin{array}{l}\text { Group A } \\
(n=25)\end{array}$ & $\begin{array}{l}\text { Group } \\
B(n=22)\end{array}$ & $t$ or $x^{2}(p)$ \\
\hline Age (years) & $72.28(4.9)$ & $72.36(5.4)$ & $\begin{array}{l}-0.56 \\
(.96)\end{array}$ \\
\hline Education (years) & $16.08(2.5)$ & $15.05(2.4)$ & $1.45(.18)$ \\
\hline Sex (\% male) & $32 \%$ & $50 \%$ & $1.57(.21)$ \\
\hline Mini-Mental State Exam total & $28.70(1.0)$ & $28.90(1.3)$ & $\begin{array}{l}-0.55 \\
(.58)\end{array}$ \\
\hline $\begin{array}{l}\text { Shipley inst of living scale } \\
\text { estimated IQ }\end{array}$ & $117.70(11.2)$ & $113.40(16.3)$ & $1.07(.29)$ \\
\hline PANAS negative sum baseline & $15.10(5.3)$ & $14.5(5.2)$ & $0.35(.73)$ \\
\hline PANAS positive sum baseline & $34.15(6.8)$ & $34.78(7.3)$ & $\begin{array}{l}-0.27 \\
(.79)\end{array}$ \\
\hline LM immediate recall, form 1 story & $13.24(4.4)$ & $12.95(3.9)$ & $0.23(.82)$ \\
\hline $\begin{array}{l}\text { LM immediate recall, form } 1 \\
\text { thematic }\end{array}$ & $5.00(1.9)$ & $5.36(1.6)$ & $\begin{array}{l}-0.70 \\
(.49)\end{array}$ \\
\hline LM immediate recall, form 2 story & $13.48(3.8)$ & $13.36(3.7)$ & $0.11(.92)$ \\
\hline $\begin{array}{l}\text { LM immediate recall, form } 2 \\
\text { thematic }\end{array}$ & $5.04(2.1)$ & $5.09(1.7)$ & $\begin{array}{l}-0.09 \\
(.93)\end{array}$ \\
\hline BVRT immediate recall, form C & $6.18(1.6)$ & $6.88(1.4)$ & $\begin{array}{l}-1.59 \\
(.12)\end{array}$ \\
\hline
\end{tabular}

[Neurobiology of Learning and Memrory, Vol 109, (March 2014): pg. 144-150. DOI. This article is (C) Elsevier and permission has been granted for this version to appear in e-Publications@Marquette. Elsevier does not grant permission for this article to be further copied/distributed or hosted elsewhere without the express permission from [Elsevier].] 
NOT THE PUBLISHED VERSION; this is the author's final, peer-reviewed manuscript. The published version may be accessed by following the link in the citation at the bottom of the page.

$\begin{array}{lccc} & \begin{array}{l}\text { Group A } \\ (\boldsymbol{n}=\mathbf{2 5})\end{array} & \begin{array}{l}\text { Group } \\ \mathbf{B}(\boldsymbol{n}=22)\end{array} & \boldsymbol{t} \text { or } \boldsymbol{X}^{\mathbf{2}(\boldsymbol{p})} \\ \text { BVRT immediate recall, form D } & 5.82(1.4) & 5.92(2.0) & \begin{array}{c}-0.20 \\ (.84)\end{array}\end{array}$

Group $A=$ arousal/neutral; Group $B=$ neutral/arousal; PANAS sum range $=10-50$; Wechsler Memory Scale III, Logical Memory story unit range $=0-25$, thematic unit sum range $=0-7$; Benton Visual Retention Test (BVRT) sum range $=0-10$.

\subsection{Materials}

\subsubsection{General cognitive measures}

To assure intact cognitive functioning and to allow evaluation of the comparability of order groups, participants were given broad cognitive tests. The Mini-Mental State Exam (MMSE; Folstein, Folstein, \& McHugh, 1975) is a screening measure for dementia. It briefly assesses orientation, attention, language, memory, visuospatial ability, etc. It is scored from 0 to 30, where scores of 26 or better generally indicating normal functioning in this age group. The Shipley Institute of Living Scale (Shipley; Zachary, 1986) is a 60-item instrument that measures vocabulary and abstract thinking, thereby allowing an estimate of verbal intelligence quotient (IQ).

\subsubsection{Arousal induction}

Muscle tension was induced by asking participants to squeeze a sand-filled latex ball (IsoFlex@ Gayla Industries). Participants were instructed on how to use the arousal device prior to the experimental task. Each participant established a baseline by exerting maximum tension for $30 \mathrm{~s}$ using his/her preferred hand. Subsequently, during the experimental protocol, participants were asked at various times to squeeze a moderate amount (i.e., $25-50 \%$ of his/her baseline pressure) for $1 \mathrm{~min}$; in other words, to squeeze the device "comfortably hard" (Courts, 1939; Nielson \& Jensen, 1994; Nielson et al., 1996; Wood \& Hokanson, 1965). This procedure typically produces a small (10-beat/minute) change in heart rate (Lynch, Schuri, \& D'Anna, 1976; Nielson et al., 1996), far less exertion than typically used in studies examining exercise effects on cognition (Chang, Labban, Gapin, \& Etnier, 2012; Lambourne \& Tomporowski, 2010; Tomporowski, 2003). Yet, such exertion produces physiological effects similar to other arousing treatments, such as epinephrine administration, including an inverted- $U$ dose response curve

[Neurobiology of Learning and Memrory, Vol 109, (March 2014): pg. 144-150. DOI. This article is (C) Elsevier and permission has been granted for this version to appear in e-Publications@Marquette. Elsevier does not grant permission for this article to be further copied/distributed or hosted elsewhere without the express permission from [Elsevier].] 
(e.g., Wood \& Hokanson, 1965), that modulate memory processes (e.g., Cahill, Prins, Weber, \& McGaugh, 1994; Clayton \& Williams, 2000; Kerfoot, Chattillion, \& Williams, 2008; Miyashita \& Williams, 2006; Nielson \& Jensen, 1994).

\subsubsection{Memory tasks}

The Logical Memory subtest of the Wechsler Memory Scale III (LM; Wechsler, 1997) is a test of auditory narrative memory (a subtype of episodic memory) with two comparable forms. Participants were presented with a short narrative, comprised of 15 significant elements, and needed to recall the story immediately after hearing it using as many of the exact words used in the original passage as possible. Story order was counterbalanced across subjects. A delayed recall test was also administered, 2 weeks later. Performance evaluation consisted of counting the number of principal events correctly recalled. A second score, evaluating 'thematic recall', which reflects more general level recall (i.e., 'gist') was also computed according to test instructions. A delayed recognition test, composed of 15 yes/no questions for each story, was also administered at the twoweek retest after recall testing. Raw score percent correct recall and proportion correct for recognition (hits - false alarms) were used rather than standardized scores.

The Benton Visual Retention Test (BVRT; Prakash \& Bhogle, 1992 ) is a standardized test of visual episodic memory composed of geometric figures with two comparable forms. Participants were presented with a series of 10 designs of increasing complexity. Each was presented for $10 \mathrm{~s}$, after which it was removed and participants were asked to draw it from memory. Test form was counterbalanced across subjects. Raw score was computed (0-10 possible for each test), based on accuracy of the elements of the reproduction according to test scoring instructions. A delayed recognition test was given after the two-week delay, which was composed of a total of 40 yes/no items (20 original targets, 10 from each list, plus 20 foil items). Total proportion correct (hits - false alarms) was used as the score.

\subsubsection{Arousal manipulation check}

The Positive and Negative Affect Schedule (PANAS; Watson, Clark, \& Tellegen, 1988) is a self-report measure assessing affective

[Neurobiology of Learning and Memrory, Vol 109, (March 2014): pg. 144-150. DOI. This article is (C) Elsevier and permission has been granted for this version to appear in e-Publications@Marquette. Elsevier does not grant permission for this article to be further copied/distributed or hosted elsewhere without the express permission from [Elsevier].] 
state on 20 descriptors (10 positive, such as 'excited', 'interested' and 'enthusiastic'; and 10 negative, such as 'nervous', 'jittery' and 'distressed'). Participants rated the extent that they experienced each descriptor on a 5-point scale, where anchors ranged from "very slightly or not at all" to "very much." Participants rated these descriptors regarding their current state at each measurement. Positive and negative sum scores were computed (with 50 points maximum on each dimension at each measure). The PANAS is a well established and extensively used measure with demonstrated reliability and validity for assessing affective state and response to stimulation (Crawford \& Henry, 2004). The PANAS subscales have been empirically linked to changes in physiological indices of affective responding (e.g., heart rate, body tempurature, fatigue; Ilies, Dimotakis, \& Watson, 2010; Watson, Wiese, Vaidya, \& Tellegen, 1999). Our own previous work has also demonstrated subjective and physiological response to isometric handgrip tension in elders (Nielson \& Jensen, 1994), and between PANAS and physiological indices using other arousal manipulations (Nielson \& Meltzer, 2009; Stone \& Nielson, 2001).

\subsection{Procedure}

Following informed consent, instruction in the use of the squeeze ball and the baseline 30-s squeeze, general demographic information and a medical history were collected, which required approximately $15 \mathrm{~min}$. Participants were then given the first LM and BVRT trials. These were each followed by an immediate recall assessment. LM always preceded BVRT. The PANAS was then administered. Afterward, Group A was instructed to grip the Isoflex ball "comfortably hard" for $1 \mathrm{~min}$, while Group B sat quietly for $1 \mathrm{~min}$. The PANAS was then administered again. Participants were then given general cognitive measures, including the MMSE and the Shipley, which required approximately $15 \mathrm{~min}$. Both groups then completed the second LM and BVRT trials, each followed by immediate recall. A third PANAS assessment was completed after a one-minute interval of squeezing the device (Group B) or sitting quietly (Group A). Thus, both groups completed one control condition and one arousal condition within the first session. Participants returned 2 weeks later and were given recall and recognition tests of both LM tests (in quasi-random order), followed by delayed recognition tests of both BVRT forms.

[Neurobiology of Learning and Memrory, Vol 109, (March 2014): pg. 144-150. DOI. This article is (C) Elsevier and permission has been granted for this version to appear in e-Publications@Marquette. Elsevier does not grant permission for this article to be further copied/distributed or hosted elsewhere without the express permission from [Elsevier].] 
NOT THE PUBLISHED VERSION; this is the author's final, peer-reviewed manuscript. The published version may be accessed by following the link in the citation at the bottom of the page.

Accuracy on these delayed tasks served as dependent variables for main study analyses.

\section{Results}

\subsection{Group demographics and baseline data}

Demographic and baseline data are shown in Table 1 . There were no significant differences between the order groups on demographic measures such as age, sex, education, and estimated IQ. The order groups were also comparable at baseline on subjective positive and negative affect, and memory task performance (i.e., immediate recall, prior to manipulation), with no effect attributable to condition order. Thus, subjective and performance differences following the manipulation are due to the manipulation, rather than to subject, order, or task comparability differences.

\subsection{Subjective response to the manipulation}

Analysis of the PANAS positive and negative sum scores was accomplished using a 2 (order; between-subjects) X 2 (valence; within-subjects) $\times 3$ (measures; within-subjects) mixed ANOVA. There were significant main effects of valence (positive ratings greater than negative ratings; $F(1,45)=227.7, p<.001, \mathrm{np} 2=.84 ;$ Fig. 1 ) and measures (arousal ratings greater than baseline or control; $F(2,90)=517.98, p<.001, n p 2=.92)$. There were also significant interactions between valence and measures $(F(2,90)=517.98, p<.001, \mathrm{np} 2=.92)$, and valence, measures and condition order $(F(2,90)=163.9, p<.00, \mathrm{np} 2=.79)$. Positive ratings always significantly exceeded negative ratings, and both increased significantly during arousal induction, relative to baseline or control. However, as can be seen in Fig. 1, no significant effects were attributable to order of conditions. Negative ratings after arousal induction approached significance (Group B slightly higher than Group $\mathrm{A}, p=.072$; all other $\mathrm{p}$ 's between order groups $>.19$ ). Thus, subjective state was intensified in a manner that was specific to the manipulation, but not specific or exclusive to either positive or negative affective tone.

[Neurobiology of Learning and Memrory, Vol 109, (March 2014): pg. 144-150. DOI. This article is (C) Elsevier and permission has been granted for this version to appear in e-Publications@Marquette. Elsevier does not grant permission for this article to be further copied/distributed or hosted elsewhere without the express permission from [Elsevier].] 


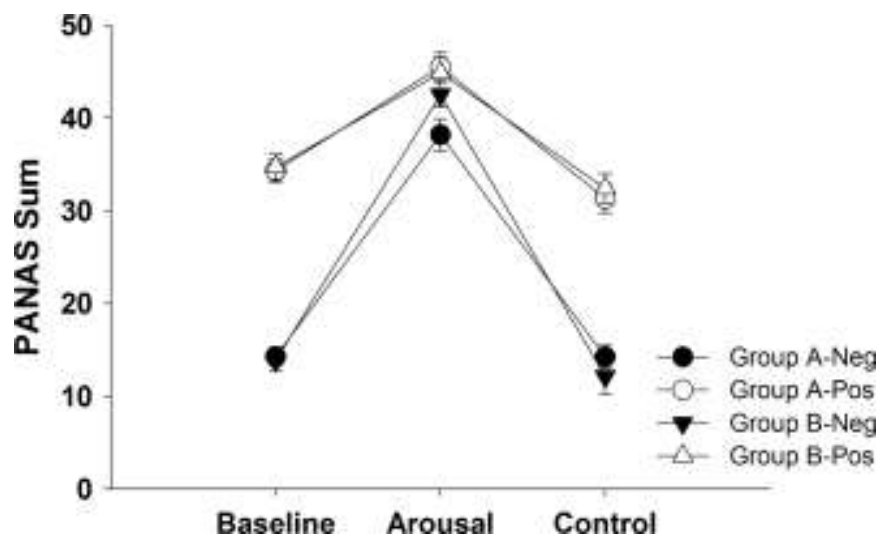

Fig. 1. Mean affective ratings (PANAS sum scores) for negative items (Neg) and positive items (Pos) taken after each study stage. Group $A=$ arousal/neutral; Group $B=$ neutral/arousal. Isometric exercise specifically altered affect ratings in both positive and negative dimensions $(p s<.001)$. There were no differences attributable to order group.

\subsection{Delayed memory test performance}

\subsubsection{Narrative memory}

Analysis of narrative memory was accomplished using a 2 (order; between subjects) X 2(condition; within-subjects) $\times 3$ (measures; within-subjects) mixed ANOVA. Measures included immediate recall (prior to manipulation), delayed recall and delayed recognition indexed as percentage correct. There were no significant main or interaction effects of order $\left(p^{\prime} s>17\right)$. There was a main effect of measures $(F(2,90)=282.11, p<.001, \mathrm{np} 2=.862)$ and condition $(F(1,45)=10.42, p=.002$, пp2 $=.188)$, as well as a significant interaction of measures $\times$ condition $(F(2,90)=4.23, p=.018, \mathrm{np} 2=.086)$. Immediate recall, prior to manipulation, did not differ between condition groups $(p=.88)$, while both delayed recall $(p=.001)$ and delayed recognition $(p=.006)$ were significantly better for stories whose encoding was followed by arousal than those followed by no arousal.

Because delayed recall performance was quite low, even though that was expected due to the two-week delay and exacting requirements for recall scoring on this task, delayed thematic recall was substituted in the analysis. Thematic recall gives more liberal credit for the ability

[Neurobiology of Learning and Memrory, Vol 109, (March 2014): pg. 144-150. DOI. This article is (C) Elsevier and permission has been granted for this version to appear in e-Publications@Marquette. Elsevier does not grant permission for this article to be further copied/distributed or hosted elsewhere without the express permission from [Elsevier].] 
to recollect the broader themes ('gist') of the story rather than solely for the specific details (Wechsler, 1997). Participant performance on thematic recall was also low, given the long retention interval, but considerably better than item recall. Moreover, ANOVA results were nearly identical to those using item recall. Once again, there were no significant main or interaction effects of order $\left(p^{\prime} s>.17\right)$. There was a main effect of measures $(F(2,90)=136.6, p<.001, \mathrm{np} 2=.76)$ and condition $(F(1,45)=13.15, p=.001, \mathrm{np} 2=.23)$, as well as a significant interaction of measures $\times$ condition $(F(2,90)=4.03, p=.021, \mathrm{np} 2=.084$; Fig. $2 \mathrm{a})$. As with the prior analysis, immediate recall, prior to manipulation, did not differ between condition groups $(p=.80)$, while both delayed thematic recall $(p=.002)$ and delayed recognition $(p=.008)$ were significantly better for stories whose encoding was followed by arousal than those followed by no arousal.
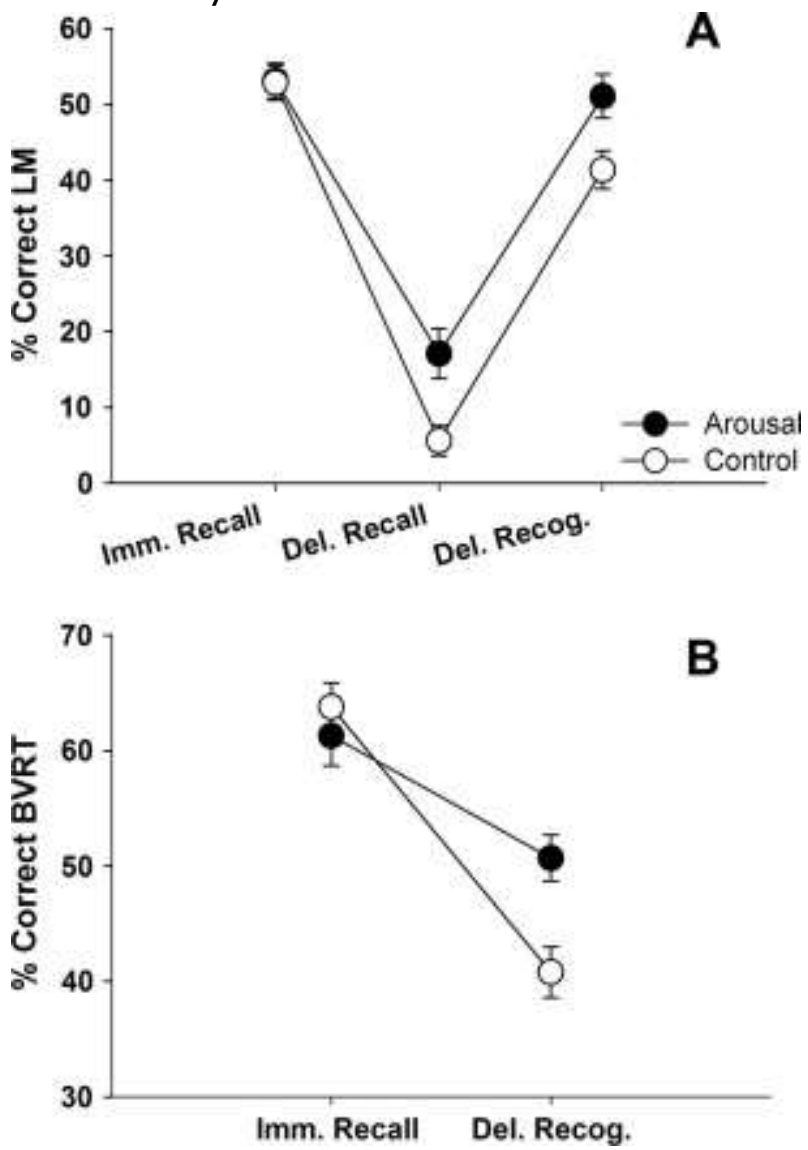

Fig. 2. Memory performance (mean percentage, \pm SEM) is shown, collapsed across order groups, by condition, for each measure on the Wechsler Memory Scale-III Logical Memory narrative memory test (A)

[Neurobiology of Learning and Memrory, Vol 109, (March 2014): pg. 144-150. DOI. This article is (C) Elsevier and permission has been granted for this version to appear in e-Publications@Marquette. Elsevier does not grant permission for this article to be further copied/distributed or hosted elsewhere without the express permission from [Elsevier].] 
and the Benton Visual Retention Test visuospatial memory test (B). Immediate recall, measured prior to the arousal manipulation, did not differ for either task. Isometric exercise after learning, relative to control, significantly enhanced delayed memory $(p s<.01)$.

\subsubsection{Visual memory}

Analysis of visual memory was accomplished using a 2 (order; between subjects) $\times 2$ (condition; within-subjects) $\times 2$ (measures; within-subjects) mixed ANOVA. Measures included immediate recall (prior to manipulation) and delayed recognition indexed as percentage correct. There were no significant main or interaction effects of order $(p ' s>.16)$. There was a main effect of measures $(F(2,44)=35.29, p<.001, \mathrm{np} 2=.445)$, a trend for condition $(F(1,44)=3.53, p=.067, \mathrm{np} 2=.18874)$, and a significant interaction of measures $x$ condition $(F(2,44)=8.22, p=.006, \mathrm{np} 2=.157$; Fig. $2 b)$. Immediate recall, prior to manipulation, did not differ between condition groups ( $p=.25)$, while delayed recognition $(p=.004)$ was significantly better for figures whose encoding was followed by arousal than those followed by no arousal.

\section{Discussion}

The present study extends the very limited literature on the effects of muscle tension-induced arousal on post-learning memory consolidation in cognitively intact older adults to narrative and visual episodic memory, two tasks that have more real-world applicability for elders than traditional list-learning tasks. Specifically, and as predicted, muscle tension induced after learning (in this case resulting from squeezing a sand-filled Isoflex (C) ball) significantly enhanced recall and recognition memory for narratives and recognition for geometric figures after a two-week retention interval. This study employed a within-subjects design, allowing for a direct comparison of story memory with and without arousal. Immediate recall, measured prior to the manipulation, as well as general cognitive testing, did not differ between groups, indicating that the groups were comparable in memory ability.

This study builds on a growing body of research examining human memory modulation and memory consolidation. Many studies

[Neurobiology of Learning and Memrory, Vol 109, (March 2014): pg. 144-150. DOI. This article is (C) Elsevier and permission has been granted for this version to appear in e-Publications@Marquette. Elsevier does not grant permission for this article to be further copied/distributed or hosted elsewhere without the express permission from [Elsevier].] 
have demonstrated dose-dependent memory modulatory effects related to peripheral doses of glucose, epinephrine, norepinephrine, and other catecholaminergic or adrenergic agents in both laboratory animals and humans (e.g., Cahill et al., 1994; McGaugh, 2000; Nielson \& Jensen, 1994; Southwick et al., 2002). Recent studies have demonstrated memory modulatory effects in human participants using various post-learning treatments that evoke physiological arousal, including those using aversive stimuli (e.g., Nielson \& Arentsen, 2012; Nielson \& Powless, 2007; Nielson et al., 2005), comedic or rewarding stimuli (e.g., Nielson \& Bryant, 2005; Nielson \& Powless, 2007) and muscle tension, which is non-specific or less polarized in terms of affect (Nielson \& Jensen, 1994; Nielson et al., 1996). The current results complement and extend the existing literature, reproducing the modulation effect via post-learning handgrip tension, and showing that arousal can enhance memory after a lengthy delay of 2 weeks in older adults.

Although aging may affect various memory functions at different rates or to different degrees (Haaland et al., 2003), both visuospatial and narrative forms of episodic memory were both susceptible to modulation. The delay interval might also be important to seeing these effects, as a number of studies have suggested that longer retention intervals better reveal the effects of memory modulation on memory consolidation (e.g., Costa-Miserachs et al., 1994; Revelle \& Loftus, 1992; Torras-Garcia et al., 1997). Furthermore, it was notable that delayed narrative recall was quite poor after the two-week delay. This was expected, given that the task involves one brief auditory presentation of the story for encoding and the scoring requirements for this task are rather exacting. As such, and because the task used for narrative memory is only standardized for a 30-min delayed retrieval interval, these results must be interpreted caution. Yet, although recall was near floor in the control condition at only $6 \%$ mean recall, performance was $67 \%$ better in the arousal condition. Narrative and visual recognition were each nearly $20 \%$ better than control. Indeed, in our earlier study that compared young with older adults, arousal improved the performance of elders to the unaroused level of young adults (Nielson \& Jensen, 1994). These results suggest that arousal after learning can substantively aid later retrieval performance across adulthood, and for multiple forms of episodic memory. Other memory types will require examination in future research.

[Neurobiology of Learning and Memrory, Vol 109, (March 2014): pg. 144-150. DOI. This article is (C) Elsevier and permission has been granted for this version to appear in e-Publications@Marquette. Elsevier does not grant permission for this article to be further copied/distributed or hosted elsewhere without the express permission from [Elsevier].] 
The preponderance of the human post-learning memory modulation literature has used verbal memory tasks to assess retention (e.g., Nielson \& Bryant, 2005; Nielson \& Jensen, 1994; Nielson \& Powless, 2007; Nielson et al., 1996, 2005; Shaw, Bekerian, \& McCubbin, 1995). Thus, the current results extend the literature to include visual and narrative episodic memory. There are some parallels to several existing studies that used inherently emotive or arousing images accompanied by verbal narratives, in which retention was better for the arousing than neutral aspects of the story (e.g., Cahill et al., 1994; O'Carroll, Drysdale, Cahill, Shajahan, \& Ebmeier, 1999; Southwick et al., 2002). Yet, the effects in these studies were predominantly attributable to the narrative elements of the stimuli. One study specifically examined emotive visual stimuli, showing that emotion-eliciting pictures were associated with elevation of blood glucose and better later retrieval than were neutral pictures (Blake, Varnhagen, \& Parent, 2001). The pictures in that study were meaningful (e.g., photographs of scenes, action, objects in relevant contexts) and the participants were asked to rate the pictures for pleasantness and emotional intensity. These verbal descriptors may have added more verbal context to the encoding and thus, aided in later recollection. The current study used simplistic, abstract visual stimuli (i.e., geometric figures) with no ratings or evaluation of them. Although they are namable (e.g., a circle with a triangle), the present design was only minimally conducive to the engagement of verbal systems to assist in remembering. Thus, the current results suggest that visual episodic memory may be susceptible to arousal-induced memory modulation in a manner consistent with verbal episodic memory. The current results also therefore support some other recent studies suggesting that memory can be modulated by semantically unrelated emotion or arousal that occurs close in time to encoding (e.g., Nielson \& Arentsen, 2012; Nielson \& Bryant, 2005; Nielson \& Jensen, 1994; Nielson \& Powless, 2007; Nielson et al., 1996, 2005), despite some other reports that suggest a semantic link or high priority for retention is necessary (Phelps, 2006; Sutherland \& Mather, 2012).

The current study also strongly supports past findings of beneficial effects of handgrip muscle tension during or immediately before memory encoding (Bills, 1927; Courts, 1939; Stauffacher, 1937; Wood \& Hokanson, 1965) as well as when it is induced after

[Neurobiology of Learning and Memrory, Vol 109, (March 2014): pg. 144-150. DOI. This article is (C) Elsevier and permission has been granted for this version to appear in e-Publications@Marquette. Elsevier does not grant permission for this article to be further copied/distributed or hosted elsewhere without the express permission from [Elsevier].] 
learning (Nielson \& Jensen, 1994; Nielson et al., 1996). The underlying mechanism of the effect was not assessed in this study, but based on prior studies, it is believed to involve modulation of the autonomic nervous system (Kluess \& Wood, 2005; Nielson \& Jensen, 1994; Stewart et al., 2006), specifically via circulating catecholamines (Cahill et al., 1994; Kremiński et al., 2012; Nielson \& Jensen, 1994) that are known to influence memory consolidation (McGaugh, 2000).

The present results, along with past research, suggest that arousal is effective and specific, even with multiple inductions or multiple learning events that occur within a short time after learning. However, recent studies suggest that arousal induced after even a fairly lengthy event, such as a college lecture, can have modulatory effects on memory for the entire event (Nielson \& Arentsen, 2012). Moreover, another study, which was consistent with multiple earlier studies in rodents, demonstrated that arousal can have effects on later retention even if induced a fairly long time after learning-in that case, 30 min afterward (Nielson \& Powless, 2007). Findings such as these might be interpreted to support the "Now print!" metaphor, which suggested that everything associated with arousal would be enhanced in memory (Livingston, 1967). Such findings might be perplexing to reconcile with the present results, where some participants learned four sets of memoranda before arousal was induced (Group B) while others learned two sets before and two sets afterward (Group A). Yet, arousal only altered memory for the memoranda recently preceding it, rather than for the entire session. Why did it not have a more general effect on the entire set of tasks learned in the session?

We hypothesize that the 'opportunity' to manipulate the consolidation of episodic memory after learning may be relatively broad and lengthy when only one learning context, or episode, exists. Specifically, arousal induced once after a lengthy, and emotionally neutral college lecture enhanced later retrieval for all of the material in that lecture but not for other material from prior or subsequent class days likely because the overarching effect of arousal was cohesive, representing topically related concepts, thereby functioning as one learning context (Nielson \& Arentsen, 2012). Thus, the episode gained heightened "importance" overall by arousal induced afterward. The scenario becomes more complex however when the memoranda vary in their affective tone (i.e., valence and/or arousal). Positive and

[Neurobiology of Learning and Memrory, Vol 109, (March 2014): pg. 144-150. DOI. This article is (C) Elsevier and permission has been granted for this version to appear in e-Publications@Marquette. Elsevier does not grant permission for this article to be further copied/distributed or hosted elsewhere without the express permission from [Elsevier].] 
negative memoranda tend to be better remembered than neutral memoranda (LaBar \& Cabeza, 2006) and some studies suggest that post-learning arousal on such episodes preferentially enhances memory for the emotive stimuli (Cahill, Gorski, \& Le, 2003; Liu et al., 2008; Nielson \& Lorber, 2009). While the specific contrasts show better long-term retention for emotive than neutral stimuli with postlearning arousal, it is notable that the main effect of condition (arousal vs. control) is also typically significant. Thus, while the advantage of emotive stimuli over neutral stimuli persists in memory and an interaction of the stimuli with the manipulation may exacerbate the effect, post-learning induction of arousal may elevate memory for the entire episode as well (Nielson \& Lorber, 2009). Yet, even in this context, the "Now print!" metaphor (Livingston, 1967) appears too broad as there is also evidence that it is 'gist' that is primarily enhanced by arousal, rather than more specific memory for details (Cahill et al., 2003; Liu et al., 2008).

However, when multiple unrelated learning events occur close in time, the link between arousal and memoranda may be more temporally specific. At least two studies prior to the current one-all from our laboratory-have used multiple learning events with postlearning arousal and control manipulations done within subjects instead of between subjects (Nielson \& Jensen, 1994; Nielson et al., 1996). Each used comparable muscle tension approaches to induce arousal and showed that arousal specifically affected only the material that was learned most recently preceding the arousal induction. The counterbalancing of condition order and analysis for order in each of these studies assured that no effects could be attributable to nonspecific arousal from prior or subsequent conditions. Furthermore, in each of these studies, multiple, quite independent learning contexts existed (i.e., separate sets of stimuli, presented as different learning 'episodes'). Thus, the effect of post-learning arousal on the modulation of memory consolidation for episodic memory, at least for neutral materials, appears to depend upon what constitutes an "episode". If material is presented cohesively, as a single episode, post-learning arousal might modulate it in its entirety, at least for gist-level information. But when multiple episodes exist, it appears to have more temporally specific effects. This interpretation would also support the view that arousal-induced modulation of memory acts to discriminate important from more trivial information and events (McGaugh, 2000;

[Neurobiology of Learning and Memrory, Vol 109, (March 2014): pg. 144-150. DOI. This article is (C) Elsevier and permission has been granted for this version to appear in e-Publications@Marquette. Elsevier does not grant permission for this article to be further copied/distributed or hosted elsewhere without the express permission from [Elsevier].] 
Weingartner \& Parker, 1984), further suggesting that it does so in an episodically cohesive manner. The present study did not directly address this hypothesis or possible contrasts between the effects of post-learning arousal induction and the effects of arousal before or during learning or when using inherently arousing stimuli or conditions; future research will be needed to more directly evaluate it.

Finally, the current study intentionally employed a simple "squeeze ball" device to additionally examine whether an effective approach could be easily integrated into an individual's daily routine, outside a laboratory environment. The 'squeeze ball' is inexpensive; requires little precision, specialized knowledge or skill to use; and is easily portable. Such techniques are particularly and increasingly needed to address or reduce the cognitive consequences of aging. Thus, the findings of the present study provide some support for further investigation of the use of this technique outside the laboratory, as a more practical memory intervention.

\section{Acknowledgments}

The authors wish to thank our participants and Gayla Industries, who graciously provided the Isoflex (c) balls, for assisting with this research.

\section{References}

M. Ariza, R. Pueyo, C. Junqué, M. Mataró, M.A. Poca, M.P. Mena, J. Sahuquillo Differences in visual vs. verbal memory impairments as a result of focal temporal lobe damage in patients with traumatic brain injury Brain Injury, 20 (10) (2006), pp. 1053-1059

\section{G. Bills The influence of muscular tension on the efficiency of} mental work, American Journal of Psychology, 38 (1927), pp. 227-251

T.M. Blake, C.K. Varnhagen, M.B. Parent Emotionally arousing pictures increase blood glucose levels and enhance recall Neurobiology of Learning and Memory, 75 (3) (2001), pp. 262273 ,

[Neurobiology of Learning and Memrory, Vol 109, (March 2014): pg. 144-150. DOI. This article is (C) Elsevier and permission has been granted for this version to appear in e-Publications@Marquette. Elsevier does not grant permission for this article to be further copied/distributed or hosted elsewhere without the express permission from [Elsevier].] 
L. Cahill, L. Gorski, K. Le Enhanced human memory consolidation with post-learning stress: Interaction with the degree of arousal at encoding Learning and Memory, 10 (4) (2003), pp. 270-274

L. Cahill, B. Prins, M. Weber, J.L. McGaugh Beta-adrenergic activation and memory for emotional events Nature, 371 (6499) (1994), pp. 702-704,

Y.K. Chang, J.D. Labban, J.I. Gapin, J.L. Etnier The effects of acute exercise on cognitive performance. a meta-analysis. [Meta-Analysis Research Support, Non-U.S. Gov't] Brain Research, 1453 (2012), pp. 87-101

R.M. Chapman, M. Mapstone, A.P. Porsteinsson, M.N. Gardner, J.W. McCrary, E. DeGrush, M.D. Guillily Diagnosis of Alzheimer's disease using neuropsychological testing improved by multivariate analyses Journal of Clinical and Experimental Neuropsychology, 32 (2010), pp. 793-808.

E.C. Clayton, C.L. Williams Noradrenergic receptor blockade of the NTS attenuates the mnemonic effects of epinephrine in an appetitive light-dark discrimination learning task. [Research Support, U.S. Gov't, P.H.S.] Neurobiology of Learning and Memory, 74 (2) (2000), pp. 135-145.

D. Costa-Miserachs, I. Portell-Cortés, L. Aldavert-Vera, M. TorrasGarcía, I. Morgado-Bernal Long-term memory facilitation in rats by posttraining epinephrine Behavioral Neuroscience, 108 (3) (1994), pp. 469-474.

F.A. Courts Relations between experimentally induced muscular tension and memorization Journal of Experimental Psychology, 25 (1939), pp. 235-256.

J.R. Crawford, J.D. Henry The positive and negative affect schedule (PANAS): Construct validity, measurement properties and normative data in a large non-clinical

[Neurobiology of Learning and Memrory, Vol 109, (March 2014): pg. 144-150. DOI. This article is (C) Elsevier and permission has been granted for this version to appear in e-Publications@Marquette. Elsevier does not grant permission for this article to be further copied/distributed or hosted elsewhere without the express permission from [Elsevier].] 
sample The British Psychological Society, 43 (2004), pp. 245265.

M.F. Folstein, S.E. Folstein, P.R. McHugh Mini-mental state: A practical method for grading the cognitive state of patients for the clinician Journal of Psychiatric Research, 12 (1975), pp. 189-198.

P.E. Gold, R.B. van Buskirk Facilitation of time-dependent memory processes with posttrial epinephrine injections Behavioral Biology, 13 (2) (1975), pp. 145-153.

K.Y. Haaland, L. Price, A. Larue What does the WMS-III tell us about memory changes with normal aging? Journal of the International Neuropsychological Society, 9 (2003), pp. 89-96.

R. Ilies, N. Dimotakis, D. Watson Mood, blood pressure, and heart rate at work: An experience-sampling study Journal of Occupational Healthy Psychology, 15 (2010), pp. 120-130.

L. Jenkins, J. Myerson, J.A. Joerding, S. Hale Converging evidence that visuospatial cognition is more age-sensitive than verbal cognition Psychology and Aging, 15 (2000), pp. 157175.

E.C. Kerfoot, E.A. Chattillion, C.L. Williams Functional interactions between the nucleus tractus solitarius (NTS) and nucleus accumbens shell in modulating memory for arousing experiences. [Comparative Study Research Support, N.I.H., Extramural] Neurobiology of Learning and Memory, 89 (1) (2008), pp. 47-60.

H.A. Kluess, R.H. Wood Heart rate variability and the exercise pressor reflex during dynamic handgrip exercise and postexercise arterial occlusion American Journal of the Medical Sciences, 329 (2005), pp. 117-123.

K. Kremiński, G. Cybulski, A. Ziemba, K. Nazar Cardiovascular and hormonal responses to static handgrip in young and older

[Neurobiology of Learning and Memrory, Vol 109, (March 2014): pg. 144-150. DOI. This article is (C) Elsevier and permission has been granted for this version to appear in e-Publications@Marquette. Elsevier does not grant permission for this article to be further copied/distributed or hosted elsewhere without the express permission from [Elsevier].] 
NOT THE PUBLISHED VERSION; this is the author's final, peer-reviewed manuscript. The published version may be accessed by following the link in the citation at the bottom of the page.

healthy men, European Journal of Applied Physiology, 112 (2012), pp. 1315-1325.

K.S. LaBar, R. Cabeza Cognitive neuroscience of emotional memory Nature Reviews Neuroscience, 7 (1) (2006), pp. 5464.

K. Lambourne, P. Tomporowski The effect of exercise-induced arousal on cognitive task performance. A meta-regression analysis. [Meta-Analysis Review] Brain Research, 1341 (2010), pp. 12-24.

D.L.J. Liu, S. Graham, M. Zorawski Enhanced selective memory consolidation following post-learning pleasant and aversive arousal Neurobiology of Learning and Memory, 89 (1) (2008), pp. 36-46.

\section{R.B. Livingston Reinforcement}

G. Quarton, T. Melnechuk, F. Schmitt (Eds.), The Neurosciences: $A$ Study Program, Rockefeller Press, New York (1967), pp. 514576.

W.C. Lynch, U. Schuri, J. D'Anna Effects of isometric muscle tension on vasomotor activity and heart rate Psychophysiology, 13 (3) (1976), pp. 222-230.

J.L. McGaugh Time-dependent processes in memory storage Science, 153 (3742) (1966), pp. 1351-1358.

J.L. McGaugh Memory - A century of consolidation Science, 287 (5451) (2000), pp. 248-251.

L. Messinis, E. Lyros, V. Georgiou, P. Papathanasopoulous Benton visual retention test performance in normal adults and acute stroke patients: Demographic considerations,

[Neurobiology of Learning and Memrory, Vol 109, (March 2014): pg. 144-150. DOI. This article is (C) Elsevier and permission has been granted for this version to appear in e-Publications@Marquette. Elsevier does not grant permission for this article to be further copied/distributed or hosted elsewhere without the express permission from [Elsevier].] 
discriminant validity, and test-retest reliability The Clinical Neuropsychologist, 23 (2012), pp. 962-977.

T. Miyashita, C.L. Williams Epinephrine administration increases neural impulses propagated along the vagus nerve: Role of peripheral beta-adrenergic receptors. [In Vitro] Neurobiology of Learning and Memory, 85 (2) (2006), pp. 116124.

K.A. Nielson, T.J. Arentsen Memory modulation in the classroom: Selective enhancement of college examination performance by arousal induced after lecture, Neurobiology of Learning and Memory, 98 (1) (2012), pp. 1216.

K.A. Nielson, T. Bryant, The effects of non-contingent extrinsic and intrinsic rewards on memory consolidation Neurobiology of Learning and Memory, 84 (2005), pp. 42-48.

K.A. Nielson, R.A. Jensen Beta-adrenergic receptor antagonist antihypertensive medications impair arousal-induced modulation of working memory in elderly humans Behavioral and Neural Biology, 63 (3) (1994), pp. 190-200.

K.A. Nielson, W. Lorber Enhanced post-learning memory consolidation is influenced by arousal predisposition and emotion regulation but not by stimulus valence or arousal Neurobiology of Learning and Memory, 92 (2009), pp. 70-79.

K.A. Nielson, M.A. Meltzer Modulation of long-term memory by arousal in alexithymia: The role of interpretation Consciousness and Cognition, 18 (2009), pp. 786-793.

K.A. Nielson, M. Powless Positive and negative sources of emotional arousal enhance long-term word-list retention when induced as long as $\mathbf{3 0} \mathbf{~ m i n}$ after learning Neurobiology of Learning and Memory, 88 (2007), pp. 40-47.

[Neurobiology of Learning and Memrory, Vol 109, (March 2014): pg. 144-150. DOI. This article is (C) Elsevier and permission has been granted for this version to appear in e-Publications@Marquette. Elsevier does not grant permission for this article to be further copied/distributed or hosted elsewhere without the express permission from [Elsevier].] 
NOT THE PUBLISHED VERSION; this is the author's final, peer-reviewed manuscript. The published version may be accessed by following the link in the citation at the bottom of the page.

K.A. Nielson, R.C. Radtke, R.A. Jensen Arousal-induced modulation of memory storage processes in humans Neurobiology of Learning and Memory, 66 (2) (1996), pp. 133142.

K.A. Nielson, D. Yee, K.I. Erickson Memory enhancement by a semantically unrelated emotional arousal source induced after learning Neurobiology of Learning and Memory, 84 (2005), pp. 49-56.

R.E. O'Carroll, E. Drysdale, L. Cahill, P. Shajahan, K.P. Ebmeier Stimulation of the noradrenergic system enhances and blockade reduces memory for emotional material in man Psychological Medicine: A Journal of Research in Psychiatry and the Allied Sciences, 29 (5) (1999), pp. 1083-1088.

M.B. Parent, C. Varnhagen, P.E. Gold A memory-enhancing emotionally arousing narrative increases blood glucose levels in human subjects Psychobiology, 27 (3) (1999), pp. 386-396.

N. Peel, H. Bartlett, R. McClure Healthy ageing: How is it defined and measured? Australasian Journal on Ageing, 23 (2004), pp. 115-119.

E.A. Phelps Emotion and cognition: Insights from studies of the human amygdala Annual Review of Psychology, 57 (2006), pp. 27-53.

I.J. Prakash, S. Bhogle Benton's visual retention test: Norms for different age groups Journal of the Indian Academy of Applied Psychology, 18 (1-2) (1992), pp. 33-36.

W. Revelle, D.A. Loftus The implications of arousal effects for the study of affect and memory S. $-\AA$. Christianson (Ed.), The Handbook of Emotion and Memory, Lawrence Erlbaum Association, Hillsdale, NJ, England (1992), pp. 113-150.

[Neurobiology of Learning and Memrory, Vol 109, (March 2014): pg. 144-150. DOI. This article is (C) Elsevier and permission has been granted for this version to appear in e-Publications@Marquette. Elsevier does not grant permission for this article to be further copied/distributed or hosted elsewhere without the express permission from [Elsevier].] 
NOT THE PUBLISHED VERSION; this is the author's final, peer-reviewed manuscript. The published version may be accessed by following the link in the citation at the bottom of the page.

E.T. Rolls Memory systems in the brain Annual Review of Psychology, 51 (2000), pp. 599-630.

D.C. Rubin The basic-systems model of episodic memory Perspectives on Psychological Science, 1 (4) (2006), pp. 277311.

M.J. Sharps Age-related change in visual information processing: Toward a unified theory of aging and visual memory Current Psychology, 16 (1998), pp. 284-307.

G.A. Shaw, D.A. Bekerian, J.A. McCubbin Effects of videotaped violence on hypermnesia for imaginally encoded concrete and abstract words Perceptual and Motor Skills, 80 (2) (1995), pp. 467-477.

S.M. Southwick, M. Davis, B. Horner, L. Cahill, C.A. Morgan, P.E. Gold, D.C. Charney Relationship of enhanced norepinephrine activity during memory consolidation to enhanced long-term memory in humans American Journal of Psychiatry, 159 (8) (2002), pp. 1420-1422.

J.C. Stauffacher The effect of induced muscular tension upon various phases of the learning process Journal of Experimental Psychology, 21 (1937), pp. 26-46.

J.M. Stewart, L.D. Montgomery, J.L. Glover, M.S. Medow Changes in regional blood volume and blood flow during static handgrip American Journal of Physiology - Heart and Circulatory Physiology, 292 (2006), pp. H215-H224.

L.A. Stone, K.A. Nielson Physiological response to arousal and impaired emotional expression in alexithymia Psychotherapy and Psychosomatics, 70 (2001), pp. 92-102.

[Neurobiology of Learning and Memrory, Vol 109, (March 2014): pg. 144-150. DOI. This article is (C) Elsevier and permission has been granted for this version to appear in e-Publications@Marquette. Elsevier does not grant permission for this article to be further copied/distributed or hosted elsewhere without the express permission from [Elsevier].] 
NOT THE PUBLISHED VERSION; this is the author's final, peer-reviewed manuscript. The published version may be accessed by following the link in the citation at the bottom of the page.

M.R. Sutherland, M. Mather Negative arousal amplifies the effects of saliency in short-term memory Emotion (2012)

P.D. Tomporowski Effects of acute bouts of exercise on cognition. [Review]Acta Psychol (Amst), 112 (3) (2003), pp. 297-324

M. Torras-Garcia, I. Portell-Cortés, D. Costa-Miserachs, I. MorgadoBernal Long-term memory modulation by posttraining epinephrine in rats: Differential effects depending on the basic learning capacity Behavioral Neuroscience, 111 (2) (1997), pp. 301-308.

D. Watson, L.A. Clark, A. Tellegen Development and validation of brief measures of positive and negative affect: The PANAS scales Journal of Personality and Social Psychology, 54 (6) (1988), pp. 1063-1070.

D. Watson, D. Wiese, J. Vaidya, A. Tellegen The two general activation systems of affect: Structural findings, evolutionary considerations, and psychobiological evidence Journal of Personality and Social Psychology, 76 (1999), pp. 820-838.

D. WechslerWMS-III: Wechsler Memory Scale Administration and Scoring Manual The Psychological Corporation, San Antonio, TX (1997).

H.J. Weingartner, E.S. Parker Memory consolidation: a cognitive perspective H.J. Weingartner, E.S. Parker (Eds.), Memory Consolidation: Psychobiology of Cognition, Erlbaum-Routledge, New Jersey (1984).

C.G. Wood, J.E. Hokanson Effects of induced muscular tension on performance and the inverted $\mathbf{U}$ function Journal of Personality and Social Psychology, 1 (1965), pp. 506-510.

[Neurobiology of Learning and Memrory, Vol 109, (March 2014): pg. 144-150. DOI. This article is (C) Elsevier and permission has been granted for this version to appear in e-Publications@ Marquette. Elsevier does not grant permission for this article to be further copied/distributed or hosted elsewhere without the express permission from [Elsevier].] 
NOT THE PUBLISHED VERSION; this is the author's final, peer-reviewed manuscript. The published version may be accessed by following the link in the citation at the bottom of the page.

\section{R.A. Zachary Shipley Institute of Living Scale: Revised Manual Western Psychological Services, Los Angeles, CA (1986).}

A.B. Zonderman, L.M. Giambra, D. Arenberg, S.M. Resnick, P.T. Costa, C.H. Kawas Changes in immediate visual memory predict cognitive impairment Archives of Clinical Neuropsychology, 10 (1995), pp. 111-123 